\title{
WESTERN SPREAD OF THE COLORADO POTATO BEETLE
}

\section{(Leptinotarsa decemlineata)}

By J. M. Aldeich, Moscow, Ialuo

Economic entomology has preserved in its archives pretty full details of the eastward advance of this insect. Starting from the arid region along the east side of the Rocky Mountains in the late fifties, when the introduction of the potato first enabled it to "switch" from its wild food-plant, Solanum rostratum, it was about fifteen years in reaching the Atlantic seacoast of the United States, and in a few years more it was omnipresent in the eastern two thirds of the country.

It is a striking fact that the advance of settlement and potatoraising west of the continental divide did not carry the beetle with it. Professor Gillette writes me lately that even yet he has looked for the insect in vain west of the main divide in Colorado. As far as I have ascertained in considerable travel through the West, there are no potato beetles on the western side of the Rockies except as noted herein.

Professor Cooley of the Montana Experiment Station writes me that it has in quite recent years established itself in the Bitter Root Valley of western Montana, although as yet it has not reached the upper end of the valley. He also finds it in Flathead County. Both of these localities are on the western side of the continental divide.

A new western record for the insect is the town of Nez Perce, Idaho, about forty miles southeast of Lewiston. It has been established in that neighborhood at least two years, and seems to have spread considerably last summer. I do not know of it elsewhere in Idaho.

Considering the numberless opportunities for the carriage of adults westward on railroads, it seems probable that the species has generally died out when introduced, before it became fairly established. I am informed on very good authority that a potato patch in Moscow, Idaho, was infested about sixteen years ago, but the insect did not reappear the following season. Our wet winters may account for its inability to maintain itself here, but that certainly will not hold good in all the territory concerned.

It would be interesting to learn what others have observed in the West, both in regard to the spread of the insect and to the agencies which appear to retard its advance. 